\title{
PERAN KAUM PEREMPUAN DALAM INDUSTRI KERAJINAN GERABAH DI DESA BANYUMULEK, LOMBOK BARAT, NUSA TENGGARA BARAT
}

\author{
Deshinta Vibriyanti ${ }^{1}$
}

\begin{abstract}
This paper aims to examine the role of women in the pottery industry in Banyumulek, West Lombok, NTB. In order the Banyumulek village community life, the pottery is not just a domestic handicraft industry which drives the family economic. Moreover, pottery is a social-cultural identity of the local community acquired handed down from ancestors. The study used a qualitative-description method. The process of data collection was done by interviewed, observation, and some related literature review.

The results show that women are the main actors in the pottery industri in Bayumulek. About 80 percent of the pottery industrial activities carried out by women. The skill hereditary inherited from mother to daughter since childhood. Furthermore, potterymaking skills is as an economic strategy for living due many women were widowed or living separately with her husband who work aboard as migrant workers. In the perspective of the local community, making pottery is women's work. If a man made the pottery, they called them as effeminate (men tend to be feminine). So that, the men task are merely transporting pottery from the site to the kiln drying and handling marketing distribution. Therefore, it takes effort to change the way local communities perspective related to the division of labor in the pottery industry. These can be the approach, assistance and dissemination of shared stakeholders in increasing the participation of men. Expected with the high participation of male will make pottery industry in Banyumulek village can be developed and brought prosperity to the rural communities.
\end{abstract}

Keywords: role, women, pottery

\section{A. Pendahuluan}

$\mathrm{P}$ erubahan sistem perekonomian dalam masyarakat membawa peru bahan pula pada alokasi ekonomi keluarga. Hal tersebut berdampak pada perubahan peran kaum perempuan dalam kontribusinya terhadap kesejahteraan keluarga. Partisipasi perempuan di pasar kerja diduga akan terus meningkat seiring dengan meningkatnya kesempatan mengenyam pendidikan, menurunnya jum lah anak yang dilahirkan, serta berbagai kemudahan teknologi yang membantu perempuan untuk menjalankan dua peran sekaligus, sebagai ibu rumah tangga dan sebagai perempuan bekerja. Bagi keluarga kelas bawah, keterlibatan seluruh anggota keluarga dalam bidang ekonomi sangat berarti. Bagi mereka yang tinggal di wilayah tertinggal dan status ekonomi miskin, peran ganda bukan suatu hal yang baru. Bahkan bagi perempuan, berperan ganda sudah ditanamkan semenjak mereka kecil oleh orang tua. Para remaja putri tidak dapat bermain bebas seperti layaknya remaja lainnya karena terbebani kewajiban bekerja untuk membantu perekonomian keluarga. (Soe trisni: 94, 1997). Para perempuan, khususnya pada keluarga miskin tidak terlalu memperdulikan pekerjaan yang akan mereka kerjakan. Sebagian besar mereka bekerja sebagai buruh dengan gaji rendah seperti pembantu rumah tangga dan pekerjaan jasa domestik lainnya (Mudzhakar, Anto, dkk: 189, 2001).

Di Desa Banyumulek, Lombok

\footnotetext{
${ }^{1}$ Penulis adalah peneliti bidang kependudukan di Lembaga Ilmu Pengetahuan Indonesia (LIPI)
} 
Barat, NTB juga demikian. Namun yang membedakan perempuan di desa ini adalah jenis pekerjaan yang digeluti. Perempuan desa Banyumulek mayoritas bekerja sebagai pengrajin gerabah. Sebagian dari mereka bekerja berkelompok berdasarkan ikatan kekerabatan keluarga. Selain merupakan keahlian yang diperoleh turun temurun, membuat gerabah juga merupakan salah satu strategi ekonomi bagi mereka. Tingginya angka perempuan yang berstatus janda dan perempuan yang ditinggal oleh suami untuk bekerja di luar negeri sebagai TKI mendorong perempuan di desa Banyumulek untuk menekuni profesi sebagai pembuat gerabah.

Gerabah adalah salah satu bentuk peradaban tertua dan universal dalam perkembnagan budaya manusia. Gerabah dapat ditemui di setiap kebudayaan di seluruh penjuru dunia dan sudah dikenal oleh manusia bahkan sejak jaman pra sejarah. Menurut ahli sejarah, gerabah atau yang biasa disebut juga dengan tembikar mulai dikenal oleh manusia sejak zaman neolitikum. Pada saat itu manusia purba mulai hidup menetap, bercocok tanam dan mengenal api (Soegondho, 1995). Manusia pada zaman tersebut mulai menyimpan bahan makanan dengan menggunakan keranjang. Untuk menghindari kebocoran di sela-sela keranjang, yang terbuat dari anyaman akar tanaman, keranjang tersebut dilapisi dengan tanah liat. Kartodirdjo (1997) menyebutkan, sebagai ganti alat-alat berupa keranjang dibutuhkan barang yang lebih kuat berupa gerabah. Gerabah dimanfaatkan untuk menyimpan makanan, upacara keagamaan dan upacara pemakaman.

Nilai-nilai yang terkandung dalam gerabah pada dasarnya menggambarkan kondisi suatu kelompok masyarakat pada zamannya. Pada zaman dulu gerabah dibuat berbentuk perkakas dapur dan alatalat rumah tangga seperti piring, bejana, gentong, mangkok, cobek, kendi, pot dan lain sebagainya. Sejalan dengan perkembangan peradaban dan penemuan teknologi, saat ini alat-alat rumah tangga tidak banyak yang berbahan dasar tanah liat, namun sudah beralih menggunakan bahan dasar yang lebih ringan seperti kaca (glass), tembaga, perak, melamin dan lain sebagainya. Sejalan dengan waktu gerabah mengalami transisi nilai kebendaan yang berawal dari nilai fungsional berkembang menjadi nilai estetika (seni). Di beberapa komunitas masyarakat kebudayaan masih menggunakan gerabah sebagai alat perlengkapan upacara adat dan keagamaan. Saat ini gerabah sebagai produk seni telah berkembang menjadi bentuk yang lebih indah sebagai penunjang dalam kehidupan. Di samping itu, produk yang dihasilkan terus mengalami perbaikan bentuk dengan desain baru berdasarkan pengalaman batin perajin (Soegondho, 1995).

Selain perkembangan dalam aspek nilai kebendaan (value goods), gerabah juga mengalami perkembangan dalam hal proses pembuatan. Diawali proses pembuatan dengan teknik yang sangat sederhana (hand building) hingga saat ini gerabah melalui proses pembuatan dengan teknologi modern. Gerabah yang paling sederhana dibentuk dengan menggunakan tangan dan memiliki bentuk permukaan yang kasar dan kadang tidak simentris. Namun saat ini pembuatan gerabah pada umumnya sudah menggunakan teknologi tatap batu dan roda putar sehingga memiliki bentuk dan nilai seni yang indah. Pada dasarnya gerabah sejak zaman dahulu hingga kini, dibuat melalui tiga proses dasar, yaitu 1) menguli/meremas-remas (kneading); 2) membentuk (forming); dan 3) membakar (firing). Namun saat ini sentuhan-sentuhan modern banyak dijumpai pada produkproduk gerabah sehingga dibutuhkan proses finishing dengan memberikan sentuhan dekorasi pada gerabah. Hal tersebut dapat terlihat dari bentuk-bentuk kreatif dan inovatif yang ditemui saat ini dalam berbagai bentuk seperti vas bunga, guci besar maupun kecil, serta bentuk-bentuk hiasan dekorasi lainnya lain.

Masyarakat Indonesia juga me ngenal gerabah sebagai salah satu ciri kebudayaan yang tersebar di seluruh penjuru nusantara. Daerah-daerah di Indonesia yang menjadi sentra kerajinan gerabah saat ini diantaranya, gerabah Takalar dari Sulawesi Selatan, gerabah Kasongan dan Pondong dari Yogyakarta, gerabah Plered dari Purwakarta, gerabah Gethakan dari Malang, gerabah Nagara dari Kalimantan Selatan, gerabah Waykanan dari Lampung, gerabah Banyumulek di Lombok Barat, gerabah Banyuning dari Bali, gerabah Sentani dari Papua dan masih 
banyak potensi-potensi kerajian gerabah dari daerah lain yang belum dikelola dengan baik.

Gerabah bagi masyarakat pengrajin desa Banyumulek tidak hanya semata bernilai ekonomi dan sebagai sumber mata pencaharian. Gerabah dinilai sebagai suatu identitas sosial dan budaya yang diperoleh turun temurun dari leluhur. Proses pembuatan gerabah yang cukup kompleks yaitu dilakukan melalui beberapa tahap pengerjaan dan membutuhkan tenaga kerja yang relatif banyak, sehingga menjadikan usaha kerajinan gerabah sebagai salah satu media integrasi sosial dalam masyarakat. Umar Kayam dalam Sudarso (2002) menyatakan bahwa kerajinan gerabah, anyam-anyaman dari bambu, ukiran kayu dalam bentuk maupun motif yang sederhana merupakan seni komunitas pedesaan yang masih akrab, homogen dan masih berfungsi untuk mengikat solidaritas komunitas.

Pembagian kerja dalam proses produksi gerabah sejak dahulu sudah dilakukan oleh laki-laki dan perempuan. Proses pembuatan gerabah melalui beberapa tahap, yaitu dimulai dari pengambilan tanah liat, persiapan tanah liat, proses pembentukan, penjemuran, pem bakaran dan yang terakhir adalah proses penyempurnaan (finishing). Setiap daerah memiliki perbedaan budaya dan tradisi dalam pembagian kerja. Di Thailand, lakilaki tidak ikut terlibat dalam produksi atau pun distribusi. Pengrajin perempuan melalukan semua proses usaha, mulai dari mengumpulkan tanah liat, melembutkan dan menggiling, menguli/meremas-remas tanah liat, membentuk gerabah, menjemur, membakar dan pada tahap akhir memberikan sentuhan dekoratif pada gerabah serta memasarkannya (Atmadja, 1991). Di daerah penghasil gerabah di Banyumulek, Lombok Barat, walaupun sebagian besar proses produksi dilakukan oleh perempuan namun untuk pemasaran dan distribusi dilakukan oleh laki-laki. Perbedaan setiap daerah penghasil gerabah dalam hal pembagian kerja menjadi hal yang menarik karena tentu saja pembagian kerja tersebut memiliki rasionalitas tersendiri berdasarkan kearifan lokal masing-masing budaya.

Penelitian-penelitian terdahulu me ngenai gerabah lebih banyak membahas proses produksi gerabah dalam perspektif budaya laki-laki. Namun sebenarnya di beberapa daerah seperti di Banyumulek, perempuan justru menjadi aktor utama. Hal ini menarik untuk dibahas karena hampir semua proses produksi dilakukan oleh kaum perempuan. Kajian ini bertujuan untuk mendeskripsikan tentang kehidupan pe rempuan pengrajin gerabah yang terdapat di Kecamatan Banyumulek, Lombok Barat, NTB. Melalui tulisan ini diharapkan dapat memberikan kontribusi kepada berbagai stakeholder yang terkait untuk meningkatkan pemberdayaan perempuan pengrajin gerabah dalam meningkatkan perekonomian keluarga.

\section{B. Kondisi Sosio-Demografi Desa Banyumulek, Lombok Barat}

erabah tidak dapat dipisahkan dari
kehidupan
Banyumulek. Dasyarakat Desa Banyumulek karena diproduksi di desa Banyumulek, kecamatan Kediri, Kabupaten Lombok Barat. Sebenarnya selain Banyumulek, di Lombok terdapat beberapa desa lain yang juga menghasilkan gerabah dengan kualitas ekspor seperti Desa Penujak, Lombok Tengah dan desa Masbagik, Lombok Timur. Kerajinan gerabah telah menjadi harapan hidup lebih dari 10.000 pengerajin yang berasal dari ketiga desa.

Desa Banyumulek berjarak sekitar $15 \mathrm{~km}$ sebelah timur Kota Mataram dengan populasi penduduk berjumlah 10.347 jiwa. Walaupun pekerjaan sebagai petani sawah masih dilakukan, namun 80 persen penduduk menggantungkan hidup dari industri kerajinan gerabah. Menurut data BPS Kabupaten Lombok Barat tahun 2007, terdapat 2.413 rumah tangga pengrajin gerabah dari total 3.203 rumah tangga di Desa Banyumulek. Dari 11 dusun di desa ini sentra gerabah tersebar di empat dusun, yaitu di Banyumulek Barat, Banyumulek Timur, Gubug Baru, dan Muhajirin. Pada tahun 2010 desa ini pecah menjadi dua desa yaitu Desa Banyumulek dan Desa Lelede. Di sekitar dusun itu berkembang penganyaman rotan dan pengusaha art shop sebagai bukti bahwa kerajinan gerabah terus berkembang dan mampu menjadi penggerak utama perekonomian desa ini. Menurut data BPS Kabupaten Lombok Barat tahun 2007, populasi 
penduduk perempuan desa Banyumulek tercatat sebanyak 4.863 orang yang tersebar di 16 dusun. Hampir $80 \%$ dari populasi perempuan tersebut terlibat dalam industri kerajinan gerabah.

Dalam pandangan masyarakat setempat, membuat gerabah adalah pekerjaan perempuan. Jika seorang suami membuat gerabah, mereka dijuluki banci (laki-laki yang cenderung feminin). Akibatnya, tugas suami hanya mengangkut gerabah dari lokasi penjemuran ke tungku pembakaran. Selain itu data dari Badan Keluarga Berencana dan Pemberdayaan Perempuan di Lombok Barat menyebutkan bahwa pada tahun 2011, dari 2.205 keluarga di Desa Banyumulek, terdapat 150 kepala keluarga perempuan berstatus janda. Data lain menyebutkan bahwa dari 10.000 jiwa lebih penduduk di desa tersebut, lebih dari 400 perempuan hidup menjanda dan sendirian menanggung beban keluarga. Kebanyakan perempuan yang menjanda itu ditinggal suaminya merantau ke Malaysia, dan sebagian besar tidak ada kabar mengenai para suami yang menjadi buruh migran itu. Kondisi demikianlah yang mendorong para perempuan untuk me ngambil alih bertanggung jawab atas kelangsungan hidup keluarganya dengan menjadi pengrajin gerabah atau dalam bahasa setempat disebut memande.

Memande yaitu membuat gerabah yang secara turun temurun menjadi keterampilan warisan leluhur. Dari kegiatan memande ini, terciptalah bermacam bentuk benda kebutuhan rumah tangga seperti tempat minum, gentong, vas bunga, periuk, dan lain sebagainya. Dari keterampilan memande inilah para perempuan pengrajin gerabah dapat bertahan hidup dan menghidupi keluarganya Sayangnya, keuntungan dari pekerjaan ini sangatlah kecil. Berjam-jam duduk mengolah gerabah, mereka hanya mendapatkan uang sebesar Rp 400 untuk satu piring tempat sambal kecil dan Rp15.000 untuk vas bunga setinggi satu meter, padahal membuat vas tersebut membutuhkan waktu selama lima hari. (www.jurnalperempuan.org/memandekegiatan-ekonomi-perempuan-lombok.html). Sedangkan dalam penelitian yang dilakukan oleh Sukardi (1997), menyebutkan bahwa kontribusi perempuan di Banyumulek terhadap perekonomian rumah tangga masing-masing mencapai $52 \%$ dimana total pendapatan rumah tangga (sekitar 70\%) bersumber dari industri gerabah.

Secara pasti belum dapat diketahui kapan dan bagaimana kerajinan gerabah menjadi keahlian masyarakat desa Banyumulek. Namun, beberapa pengrajin tua di desa Banyumulek menyebutkan bahwa nenek moyang mereka membawa keahlian membuat gerabah yang berasal dari Kerajaan Majapahit pada abad ke-15. Para pengrajin gerabah yang telah lanjut usia menyebutkan bahwa mereka telah membuat gerabah sejak umur mereka masih kecil. Keahlian tersebut mereka peroleh dari orang tua mereka dan kemudian mewariskannya kepada generasi selan jutnya. Oleh karena itu para pengrajin gerabah di Lombok lebih banyak yang merasa bahwa mereka sebagai pekerja tangan yang ahli membuat gerabah dari pada sebagai seorang seniman.

Gerabah yang telah menjadi bagian dalam kehidupan masyarakat Banyumulek dapat tercermin dari bentuk dan struktur bangunan rumah tradisional penduduk. Rumah tradisional penduduk di Banyumulek pada umumnya terbuat dari kayu dan dibangun di atas tiang-tiang (berbentuk panggung) dengan tujuan menghindari luapan sungai Babak. Sehari-hari, bagian bawah rumah (kolong) dimanfaatkan sebagai tempat untuk melakukan aktivitas membuat gerabah, tempat bersosialisasi dan kadang menjadi tempat tidur. Hal tersebut sangat dimungkinkan karena jarak lantai rumah yang cukup tinggi dari permukaan tanah. Namun sejalan dengan meningkatnya kesejahteraan masyarakat dan pengaruh modernisasi telah banyak penduduk yang menganti rumah tradisional mereka dengan bangunan modern. Salah satu ciri bangunan modern terlihat dari dinding yang terbuat dari tembok bata, atap genteng dan jendela yang terbuat dari kaca. Menurut masyarakat setempat, walaupun rumah dengan konstuksi modern tidak sedingin dan sesejuk rumah tradisional yang berbahan kayu tua dan bambu serta beratap jerami, namun rumah modern menurut mereka lebih mudah dirawat dan sebagai salah satu lambang kemakmuran (pride) pagi pemiliknya. 


\section{Peran Perempuan dalam Produksi Gerabah Banyumulek}

$\mathrm{V}$ incentelli (2006), peneliti kajian tentang jender dan gerabah, yang telah melakukan penelitian hampir ke seluruh benua di dunia, menyebutkan bahwa dalam tradisi Timur, empat dari lima masyarakat pengrajin gerabah adalah perempuan. Menurut Vincentelli, peran perempuan dalam disain sebuah karya seni sering diabaikan, sehingga banyak penelitian tentang karya seni termasuk gerabah, yang bias jender. Vincentelli juga banyak mengkritisi hasil-hasil penelitian ahli sejarah dari Barat yang menggunakan perspektif maskulin. Menurut ahli sejarah Barat, peran perempuan Barat dalam produksi gerabah hanya sebatas dekorasi saja sedangkan laki-laki mengambil peran sebagai disainer. Ahli sejarah dari Barat juga mempercayai bahwa aktor utama dalam proses produksi gerabah adalah lakilaki. Namun pernyataan tersebut dibantah oleh Vincentelli yang telah melakukan penelitian mengenai gerabah di beberapa negara di Eropa, Afrika, dan Asia. Menurutnya para pembuat gerabah di berbagai belahan dunia yang ditemuinya kebanyakan adalah perempuan.

Dalam teknik produksi gerabah pun, terdapat perbedaan metode antara pengrajin laki-laki dan perempuan. Menurut para ahli sejarah Barat, laki-laki membuat gerabah dengan menggunakan dudukan berputar (wheels), sedangkan perempuan tetap menggunakan teknik tradisional yaitu menggunakan tangan (hand-building). Saat ini perempuan pengrajin gerabah tetap resisten terhadap metode 'maskulin' dan lebih memilih mengunakan tangan dan teknologi rendah untuk menjaga sebuah tradisi. Pada kenyataannya teknik pem buatan gerabah secara tradisional justru sangat diminati oleh para wisatawan. Tidak hanya produk hasil yang dijual namun proses pembuatan gerabah dapat dikemas sebagai wisata atraksi yang menjadi daya tarik wisatawan. Demonstrasi proses pembuatan gerabah dengan teknik tradisional dapat menjamin keaslian suatu produk (authenticity of product) (Vincentelli, 2006).

Dalam proses produksi gerabah, perempuan banyak terlibat dalam aktivitas produktif antara lain: pembentukan gerabah dari adonan tanah liat, membentuk gerabah, pembakaran gerabah, pengecatan dan finishing, kontrol kualitas dan penjualan. Sementara pekerjaan pendukung dalam pembuatan gerabah seperti membakar dan menghias (melukis dan mengukir) gerabah, menyediakan bahan baku, dan menjual gerabah biasanya dibantu oleh tenaga lakilaki. Berikut ini penjelasan secara singkat mengenai peran perempuan dalam proses pembuatan gerabah di desa Banyumulek.

\section{a. Persiapan Tanah Liat}

Tanah liat sebagai bahan baku pembuatan gerabah dapat ditemukan di sekitar desa. Perempuan pengrajin gerabah biasanya menggali tanah liat dengan menggunakan tangan dan kemudian membawanya ke rumah dengan meng gunakan keranjang rotan. Keranjang rotan berisi tanah liat dibawa dengan cara meletakkannya di atas kepala atau mengaitkannya di kedua ujung sebuah galah (dipanggul). Dalam bahasa lokal tanah liat sebagai bahan baku gerabah disebut "tanak malit". Warna tanah liat merupakan salah satu dasar dalam mengklasifikasikan jenis gerabah yang dihasilkan. Tanah liat bahan baku gerabah bisa berwarna merah, kuning, hijau atau hitam. Warna dasar tanah liat akan menghasilkan warna yang berbeda pada gerabah ketika melalui tahap pembakaran.

Menurut informasi ahli geologi, gerabah Banyumulek memiliki keunikan tersendiri dibandingkan produk sejenis yang dihasilkan oleh sentra produksi lain. Hal tersebut disebabkan karena keunikan jenis bahan baku tanah liat yang digunakan. Bahan tanah liat gerabah Banyumulek memiliki tingkat penyusutan yang lebih rendah sehingga lebih cepat matang dalam pembakaran. Bahan baku tanah liat banyak ditemui di daerah sekitar desa seperti di ladang atau kadang juga ditemukan di sawah. Menurut perempuan pengrajin gerabah, tanah liat terbaik adalah tanah liat yang berasal dari lapisan dalam tanah yang terletak pinggir bukit-bukit kecil. Pada umumnya, lahan-lahan tempat penggalian tanah liat tersebut merupakan kepemilikan seseorang. Para pengrajin tidak bisa dengan leluasa mengambil tanah liat di lahan milik orang lain. Terlebih lagi jika musim hujan datang, dimana lahan-lahan 
tersebut biasanya ditanami oleh padi, para pengrajin akan mencari alternatif lokasi tanah liat lainnya.

Dalam menemukan sumber tanah liat baru, para pengrajin harus memiliki kemampuan dalam 'menilai' jenis tanah liat. Pengalaman dan pengetahuan yang didapat secara turun temurun merupakan modal dasar bagi para pengrajin. Pengujian tanah liat tidak hanya melihat tekstur dan kepadatan tanah saja namun tidak jarang pengujian dilakukan dengan melihat warna, mencium bau tanah, bahkan mengecap rasa tanah liat tersebut. Sejalan dengan mulai berkurangnya sumber tanah liat dan keterbatasan akses perempuan pengrajin dalam memperoleh tanah liat, maka saat ini pola pembelian tanah liat kepada pemilik lahan dan kemudian diantarkan langsung ke rumah pengrajin banyak dijumpai. Menurut salah satu sumber menyebutkan, para pengrajin membayar kepada pemilik lokasi tanah sekitar Rp 300.00 per satu mobil pick up. Biasanya tanah liat tersebut berasal dari daerah pegunungan Sasak, sebelah selatan pelabuhan Lembar, berjarak sekitar 10 kilometer dari desa Banyumulek. Satu mobil pick up tanah liat tersebut cukup untuk memproduksi gerabah selama satu hingga dua minggu.

\section{b. Proses Pembentukan Gerabah}

Sebelum melakukan proses penga dukan bahan dasar, yang terdiri dari tanah liat, pasir, dan air, tanah liat terlebih dahulu mengalami proses perendaman selama 2 3 hari. Proses perendaman itu disebut sebagai sistem basah. Proses ini berguna untuk menyaring tanah liat dari kerikil-kerikil kecil yang masih menempel pada tanah liat. Sementara menunggu rendaman tanah liat selesai, pasir disaring untuk menghasilkan pasir yang benar-benar halus. Pasir sebagai bahan campuran tersebut biasanya diambil dari pinggiran sungai yang melintas sekitar 300 meter dari desa Banyumulek (Kali Babakan). Salah satu keunggulan gerabah Banyumulek juga terdapat pada jenis pasir yang digunakan. Kandungan pasir kuarsa yang cukup tinggi, koalin yang bagus, dan juga dilengkapi dengan sertifikat tidak beracun, sehingga aman sebagai tempat menyajikan makanan (Bappeda, 2011). Setelah proses perendaman selesai dan pasir telah disaring, kedua bahan tersebut dicampurkan/diuli hingga menghasilkan bahan dasar gerabah yang mudah dibentuk sesuai dengan desain yang diinginkan.

$$
\text { Dalam proses pembentukan }
$$

gerabah, pengrajin Banyumulek masih menggunakan peralatan sederhana seperti: sepotong bambu, botol kecil bekas, alat pemutar yang terbuat dari kayu, kulit kelapa, kain, dan pisau sabit yang bekas. Tanah liat yang siap dibentuk diletakkan di kayu putaran kemudian dibentuk dengan tangan oleh pengrajin. Teknik pembuatan gerabah Bayumulek sedikit berbeda dengan gerabah lainnya. Pembentukan gerabah dilakukan sedikit demi sedikit dengan menam bahkan/menempelkan tanah liat berupa gulungan (coiled). Setelah dibentuk dengan tangan kemudian permukaan gerabah dihaluskan dengan menggunakan sepotong bambu/kayu dan sebilah sabit bekas hingga pori-pori permukaan gerabah benar-benar halus. Setelah digosok dengan batu atau botol bekas, gerabah lalu dibiarkan kering selama $5-7$ hari sampai benar-benar kering dan siap untuk pembakaran.

\section{c. Pembakaran Gerabah}

Secara teknis, proses pembakaran gerabah baru dapat dilakukan jika gerabah dalam kondisi benar-benar kering. Keunggulan gerabah Banyumulek juga dapat dilihat dari proses pembakarannya. Para pengrajin gerabah Banyumulek tetap mempertahankan teknik pembakaran tradisional, yaitu dengan menggunkan jerami dan kayu bakar (tenunuq lendang) yang banyak dilakukan di tengah kebun. Proses pembakaran membutuhkan bahanbahan seperti: kayu bakar, serabut kulit kelapa, jerami/daun bambu kering, minyak tanah dan batu bata yang sudah pecah sebagai alas untuk meletakkan gerabah. Teknik pembakaran seperti ini memiliki keuntungan diantaranya adalah kemudahan dalam mengeluarkan gerabah dari tungku serta keleluasan dalam mewarnai atau menambah hiasan/ornamen pada gerabah saat pembakaran sedang berlangsung.

Sebelum dibakar, gerabah terlebih dahulu dilumuri dengan sejenis campuran cairan yang terbuat dari tanah liat, okar, dan minyak solar. Cairan tersebut bertujuan untuk menghaluskan dan membuat permukaan gerabah menjadi mengkilap. Setelah dilumuri cairan tersebut gerabah 
dikeringkan 4 - 5 jam sebelum dimasukkan ke dalam tungku pembakaran. Proses pembakaran gerabah biasanya berlangsung sekitar $3-4$ jam. Sambil proses pem bakaran berlangsung, proses pewarnaan juga dilakukan oleh pengarajin. Para pengrajin gerabah Banyumulek melakukan dua teknik pewarnaan yang alami. Pertama, pewarnaan menggunakan bahan dasar kulit asam yang disemprotkan ke permukaan gerabah disaat gerabah dalam kondisi panas. Pewarnaan dengan menggunakan kulit asam ini merupakan salah satu kekhasan produk gerabah Banyumulek. Warna yang dihasilkan nantinya spesifik berupa bercak-bercak kecoklatan pada permukaan gerabah.

Kedua, pewarnaan dengan meng gunakan rumput kering atau bekas gergaji. Caranya dengan menggulingkan gerabah yang panas di atas rumput kering atau bekas gergaji beberapa menit.

\section{d. Finishing}

Setelah melalui proses pembakaran, gerabah pun masuk pada tahap penyelesaian (finishing). Tahap ini me rupakan tahap penting untuk mengubah tampilan gerabah yang masih polos dan kasar menjadi gerabah yang menarik dan bernilai seni tinggi. Oleh karena itu, biasanya para pengrajin secara kreatif melakukan inovasi-inovasi dalam ornamenornamen gerabah. Teknik dekorasi dengan menempelkan tanah liat pada permukaan gerabah merupakan salah satu teknik lama yang masih digunakan oleh pengrajin gerabah Bayumulek. Masyarakat setempat menyebutnya dengan istilah "tenempel". Adapun beberapa teknik ornamen yang adalah: ornamen ukir kerik, ornamen tempel kulit telur, ornamen tempel pasir, ornamen anyaman rotan (ketak lombok), dan ornamen tempel kain/batik. Sedangkan motif-motif gerabah khas Banyumulek banyak dipengaruhi oleh motif suku Sasak yang merupakan suku asli masyarakat Lombok. Berbeda dengan produksi gerabah desa Masbagik dan Penunjak yang bermotifkan binatang laut dan motif orang, gerabah Banyumulek banyak menampilkan motif-motif tanaman di permukaan gerabah.

Perempuan pengrajin gerabah dinilai sebagai pembawa identitas budaya di era gobalisasi saat ini. Mereka beradaptasi dengan dinamis terhadap kondisi dan kesempatan yang baru melalui pameranpameran, demonstrasi dan bisnis pariwisata (Vincentelli, 2006). Hal tersebut didorong oleh permintaan pasar pariwisata yang menuntut pengrajin gerabah untuk melakukan diversifikasi produk secara kreatif. Pada gerabah Banyumulek, perubahan tersebut dapat terlihat dari bentuk, motif, warna dan ornamen-ornamen gerabah yang semakin variatif. Contohnya ornamen anyaman rotan yang menghiasi permukaan gerabah Banyumulek yang hingga kini sangat diminati oleh konsumen. Pada awalnya gerabah Banyumulek tidak menggunakan ornamen tersebut sebagai salah satu ciri khas produk mereka. Ide melapisi gerabah dengan anyaman rotan diyakini oleh masyarakat pengrajin terinspirasi dari botol minuman petani tradisional setempat yang terbuat dari rotan kering. Melalui intervensi program pelatihan dari pemerintah daerah, akhirnya masyarakat pengrajin mulai me ngaplikasikan anyaman rotan di setiap produk gerabah yang mereka produksi. Saat ini, geramah dengan ornamen anyaman rotan menjadi salah satu ciri khas gerabah Banyumulek.

Jika menyaksikan pembuatan gerabah secara langsung dapat dipahami mengapa pengrajin pada zaman dulu bahkan hingga kini di beberapa kebudayaan, dipercaya sebagai tukang sulap (McKinnon, 1996). Berawal dari setumpuk tanah yang tidak berbentuk dalam sekejap dapat berubah menjadi bentuk pot yang indah. Sejarahnya dahulu, perempuan di desa Banyumulek berprofesi sebagai penenun. Hanya segelintir kelompok masyarakat yang memiliki keahlian sebagai pembuat gerabah. Seorang perempuan yang tidak memiliki leluhur (keturunan) seorang pengrajin gerabah tidak akan menjadi seorang pengrajin gerabah, karena menjadi seorang pengrajin gerabah diyakini diperoleh melalui garis keturunan keluarga yaitu dari seorang ibu kepada anak perempuannya. Namun demikian, seorang pengrajin tidak dapat bekerja sendirian. Proses pembuatan gerabah yang melalui tahapan yang banyak membutuhkan bantuan pekerja lainnya. Biasanya seluruh anggota keluarga ikut membantu proses pembuatan gerabah. Bagi pekerja anak- 
anak, biasanya upah yang diberikan berupa makanan, baju dan biaya sekolah.

Hubungan satu keluarga pengrajin dengan tetangga pengrajin yang berdekatan cukup unik. Mereka biasanya mengenal spesialisasi produk. Tingkat keahlian mereka dalam membuat berbagai jenis gerabah (gerabah besar,sedang, dan kecil) berbeda-beda antar kelompok pengrajin. Sebuah keluarga pengrajin tidak akan membuat tipe produk yang sama dengan keluarga pengrajin lainnya. Misalnya seorang pengarajin memproduksi gentong, vas dan ceret maka keluarga yang lain akan memproduksi gerabah bentuk lain. Kalaupun harus memproduksi tipe yang sama biasanya spesialisasi dilakukan berdasarkan ukuran produk.

Gerabah Banyumulek secara luas dapat diterima baik oleh pasar lokal maupun internasional. Hal ini terlihat dari meningkatnya permintaan gerabah Banyumulek awal tahun 1990-an. Gerabah pada masa itu menjadi konsumsi hotel berbintang, majalah-majalah disain dan seni, serta dijadikan ikon promosi pariwisata Indonesia di luar negeri. Puncaknya ketika gerabah Ceret Lombok dipamerkan dalam ajang bergengsi Fletcher Challenge International Ceramics Exhibition pada tahun 1993. Pada ajang itu, gerabah Lombok adalah satu-satunya kerajinan gerabah desa se-Asia yang dipamerkan. Sejak saat itu kerajinan gerabah yang dulunya dipandang sebagai pekerjaan dengan 'tangan kotor', bertransformasi menjadi status sosial yang baru. Pendapatan pengrajin gerabah yang meningkat menjadikan profesi ini dipandang lebih prestisius oleh masyarakat desa selain pengrajin. Khususnya bagi perempuan pengarajin gerabah, status sosial sebagai pengrajin kecil kemudian berubah drastis ketika proses pembuatan gerabah mulai 'dikonsumsi' oleh turis, fotografer dan pembuat film dalam dan luar negeri. Menurut para pengrajin, meningkatnya permintaan gerabah secara langsung meningkatkan perekonomian keluarga masyarakat desa setempat yang berdampak pada banyaknya anak-anak dari keluarga pengrajin yang bersekolah, hutang-hutang keluarga terlunasi dan secara jelas terlihat dari banyaknya rumah-rumah yang direnovasi menjadi rumah permanen. Dalam hal ini kerajian gerabah berperan sebagai mesin pendorong terjadinya mobilitas sosial dalam masyarakat Lombok, khususnya Desa Banyumulek.

\section{Sistem Pemasaran Gerabah di Banyumulek}

$\mathrm{D}$ ahulu sistem pemasaran gerabah masih bersifat tradisonal dengan jangkauan pemasaran yang tidak luas. Pedagang keliling adalah bagian dari masyarakat usaha gerabah yang memiliki peran cukup penting dalam sebuah jaringan pemasaran. Pengrajin gerabah menjual hasil produksi kepada pedagang keliling dan kemudian pedagang keliling menjajakannya dengan cara memikul gerabah berjalan kaki di sekitar desa terdekat. Tawar menawar harga terjadi antara pengarajin dengan pedagang. Biasanya pedagang dengan mudah dapat menekan harga dengan menggunakan alasan kualitas gerabah yang kurang baik saat menemukan sedikit retakan atau permukaan gerabah yang tidak mulus. Jika kesepakatan harga telah tercapai maka pedagang akan menyusun gerabah-gerabah dengan hati-hati ke dalam keranjang, menyeimbangkannya di kedua keranjang, lalu memikulnya dengan berjalan kaki. Pedagang keliling ini akan menjajakan gerabah sampai beberapa hari hingga semua gerabah terjual. Menurut mereka hal tersebut lebih menguntungkan dibanding melakukan perjalanan ke pasar dengan resiko kemungkinan pecah/retak pada gerabah ketika sampai di pasar. Pedagang keliling kebanyakan adalah suami-suami pengrajin gerabah atau warga desa laki-laki lainnya. Sedangkan bagi perempuan pengrajin yang hanya menggantungan hidup dari usaha membuat gerabah, serta tidak memiliki tenaga kerja keluarga yang dapat membantu melakukan proses pembakaran sendiri, biasanya memilih untuk menjual gerabah kepada pedagang dalam kondisi belum dibakar (setengah jadi). Tentu saja dengan harga yang lebih rendah dibanding dengan gerabah yang sudah melalui proses pembakaran.

Sejalan dengan waktu terjadi perubahan situasi pemasaran di tiga desa sentra produksi gerabah (Banyumulek, Penujak, dan Masbagik). Awal tahun 1980an pun menjadi tahun bersejarah bangkitnya perekonomian Lombok melalui produksi gerabah. Hal ini tentu saja tidak terlepas dari 
intervensi pemerintah melalui berbagai program pembimbingan seperti pelatihan, penguatan modal, dan promosi bagi pengrajin gerabah maupun para penggerak usaha gerabah lainnya. Strategi pemasaran yang dibuat sejalan dengan penguatan sektor pariwisata di pulau Lombok dinilai tepat. Hal tersebut berimbas pada bergairahnya komoditas-komoditas lain selain gerabah, misalnya kain tenun, anyaman rotan, ukiran kayu dan lain sebagainya.

Perubahan yang sangat drastis terlihat di desa Banyumulek. Pada akhir tahun 1980, suasana desa Banyumulek sangat tenang dan hanya ramai di saat hari pasar saja. Tidak ada aktivitas yang terlihat menonjol selain hilir mudik pedagang keliling yang menjajakan gerabah dengan berjalan kaki atau menggunakan kereta kuda. Namun saat ini, kondisi desa tersebut tidak demikian lagi. Desa Banyumulek telah bertransformasi menjadi desa yang sibuk dengan hilir mudik arus mobil dan truk pengangkut gerabah ke pulau Bali dan Jawa. Selain itu permintaan gerabah dari luar negeri pun cukup banyak terutama dari negara-negara di Eropa dan Amerika. Tokotoko seni (art shops) dan galeri pun telah dibangun di sepanjang jalan masuk utama. Tidak jarang kita menemukan wisatawan baik domestik maupun manca negara yang berkunjung ke desa ini untuk menikmati wisata baru yang atraktif yaitu menyaksikan pembuatan gerabah langsung dari pengrajin gerabah. Gerabah Banyumulek telah berperran sebagai menjadi menggerak ekonomi utama desa Banyumulek.

\section{E. Program Pemberdayaan Perempuan Pengrajin Gerabah}

alah satu studi tentang peran
perempuan yang bekerja pada
produksi bahwa faktor utama yang mendorong perempuan bekerja pada usaha kerajinan gerabah adalah faktor ekonomi. Semakin sempitnya lahan pertanian dan berkurangnya kepemilikan lahan membuat pertanian dinilai tidak mampu lagi menjadi sumber mata pencaharian pokok keluarga. Oleh karena itu dibutuhkan kegiatan ekonomi di luar pertanian yang dapat menopang perekonomian keluarga seperti industri rumah tangga atau industri kecil.
Mengingat pekerjaan di sektor pertanian yang bersifat musiman, maka memungkinkan bagi keluarga petani untuk melakukan kegiatan non pertanian untuk menambah penghasilan keluarga. Walaupun dalam kasus Desa Banyumulek para perempuan pengrajin bukan berasal dari keluarga petani namun dorongan ekonomi tetap menjadi alasan utama perempuan bekerja sebagai pengrajin gerabah.

Faktor alokasi waktu pun menjadi alasan yang rasional bagi perempuan untuk menggeluti usaha ini. Perempuan dinilai memiliki keleluasaan dalam penggunaan alokasi waktu karena peran domestik yang dimiliki. Para perempuan pengrajin bekerja setelah selesai melakukan pekerjaan rumah tangga. Rata-rata mereka bekerja 7 - 8 jam sehari, baik yang bekerja di rumah sendiri maupun bekerja di tempat pengusaha gerabah yang masih kerabat. Dari wawancara dengan perempuan pengrajin gerabah, mereka menyatakan bahwa membuat gerabah adalah kegiatan yang menyenangkan dan tidak merasa terbebani. Hal tersebut karena selain mendapatkan penghasilan, mereka bekerja tidak terikat dengan waktu dan tidak meninggalkan tugas-tugas sebagai ibu rumah tangga. Sebuah penelitian yang dilakukan oleh Berata (2011), menunjukkan bahwa dalam pengembangan industri kerajinan gerabah di Pulau Lombok, ibu rumah tangga memegang peranan yang paling dominan, baik dilihat dari waktu yang dicurahkan maupun keterlibatannya pada seluruh rangkaian kegiatan proses produksi. Pembahasan penelitian ini dititikberatkan pada pola pembinaan, peluang pengembangan industri kerajinan gerabah, peran yang dilakukan beberapa pihak swasta seperti Lombok Craft Project, proses produksi, analisis biaya dan pendapatan industri kerajinan gerabah saat itu, serta analisis ekonomi peran ibu rumah tangga pada industri kerajinan gerabah.

Potensi sumber daya kaum perempuan di desa Banyumulek disadari merupakan modal dasar peningkatan perekonomian masyarakat setempat. Namun mayoritas perempuan di desa ini memiliki tingkat pendidikan yang rendah. Hal tersebut berdampak pada kemampuan yang sangat terbatas dalam manajemen usaha, akses terhadap informasi harga, dan 
ketrampilan bernegosiasi. Hal ini dipotret dengan baik oleh pemerintah derah dan beberapa NGO dari luar negeri. Pada tahun 1988, terbentuk kerja sama antara pemerintah New Zealand dengan Pemerintah Indonesia dalam hal peningkatan kapasitas perempuan pengrajin gerabah di Lombok yang dikenal dengan Lombok Craft Project (LCP). Program pemberdayaan pengrajin gerabah ini tidak hanya mengucurkan pendanaan/modal saja namun juga melakukan pelatihan-pelatihan dan pendampingan baik dari aspek teknis maupun pemasaran. Melalui pelatihan itu terjadi perubahan orientasi jenis gerabah yang diproduksi. Jika sebelumnya masih memproduksi aneka barang rumah tangga tradisonal seperti tempat air, tempat menyimpan makanan, wadah menyajikan makanan dan lain-lain, maka saat ini terjadi peningkatan ragam dan kualitas prosuk gerabah yang menyesuaikan dengan selera pasar.

Melihat perkembangan produksi yang meningkat, melalui LCP kemudian didirikan Lombok Pottery Center (LPC) sebagai saluran komersial karya gerabah. Pada tahun 2000, penjualan melalui LPC mencapai Rp. 2,5 milyar dengan keuntungan bersih $\mathrm{Rp}$ 1,7 milyar. Nilai ekspor diperkiraan pada tahun yang sama menacapai US\$ 1.5 juta. Sebagian keuntungan disalurkan ke bagian pengembangan masyarakat untuk mendanai kegiatan pembangunan, operasional dan staf termasuk distribusi bonus untuk para pengrajin dan staf sebagai pemghargaan atas kinerja merka yang baik.( www.yskk.org/program/ekonomi-kerakyatan /pengembangan-koperasi-pengrajin-gera bah)

Program LCP yang didanai oleh pemerintah New Zealand dinilai berhasil meningkatkan pemberdayaan perempuan pengrajin gerabah di Lombok. Oleh karena itu dipandang perlu untuk melembagakan program ini menjadi bentuk wadah dengan status hukum yang baru. Diharapkan status hukum yang baru ini berbasis masyarakat dan mengarah pada keberlanjutan (sus tainability) dan kemandirian. Akhirnya dibentuklah program pengembangan koperasi perempuan pengrajin gerabah. Program Pengembangan Koperasi Perempuan Pengrajin Gerabah merupakan program yang dirancang untuk mempersiapkan masyarakat (pengrajin gerabah) agar mampu mengelola aktivitas yang telah diinisiasi oleh LCP secara mandiri dan berkelanjutan lewat pem bentukan koperasi dan perseroan terbatas (PT).

Pemberdayaan perempuan peng rajin gerabah sepertinya membuahkan hasil. Selain hasil perekonomian masyarakat yang meningkat, munculnya kader-kader perem puan yang aktif mendorong pemberdayaan kaumnya. Salah satunya adalah ibu Nurul Aini. la adalah salah satu warga desa Banyumulek yang memiliki dedikasi tinggi dalam upaya meningkatkan pemberdayaan perempuan desa Banyumulek, khususnya dalam usaha gerabah. Ibu Aini mengambil peran sebagai penampung produk kerajinan gerabah di desa Banyumulek. Bukan sekedar menampung hasil produksi peng rajin gerabah, bu Aini juga melakukan pembimbingan melalui program pember dayaan, pelatihan, dan pendidikan bagi perempuan pengrajin.

$\mathrm{Bu}$ Aini juga memprakarsai berdirinya sebuah koperasi simpan pinjam yang diberi nama Al Madiah. Anggota koperasi tidak dapat meminjam modal perorangan namun harus berbentuk kelom pok tanggung-renteng yang beranggotakan 10-15 orang. Sistem ini dinilai tepat untuk menumbuhkan rasa memiliki bagi setiap anggota koperasi. Selain itu dengan menerapkan sistem ini, kemungkinan kerugian koperasi yang disebabkan oleh tunggakan pinjaman anggota dapat terhindarkan karena kelompok merupakan penjamin utama. Hingga kini koperasi Al Madiah beranggotakan 135 orang anggota dan semuanya adalah perempuan.

Belum berhenti sampai di sana saja, Bu Aini juga memiliki perhatian yang serius terhadap bidang pendidikan anak usia dini. la pun merintis berdirinya taman kanakkanak pada tahun 1993. Dengan bantuan dari Japan International Cooperation Agency (JICA) maka berdirilah gedung TK yang diberi nama Raudatul Anfal. Kebijakan sekolah yang unik terlihat dari keber pihakannya terhadap keluarga yang kurang mampu dalam hal pembiayaan. Uang sekolah terhitung murah hanya $\mathrm{Rp}$ 10.000/bulan bagi masing-masing siswa. Bagi keluarga siswa yang kurang mampu biaya tersebut boleh dicicil bahkan pihak sekolah pun menerima pembayaran dengan 
menggunakan gerabah. Menurut pengurus sekolah, hal ini terbukti berhasil mendorong partisipasi siswa sekolah karena sebelumnya banyak ditemui anak-anak yang absen atau putus sekolah karena harus membantu pekerjaan orang tuanya di rumah. Kini usaha gerabah orang tua siswa tetap bisa berjalan dan anak-anak pun tetap bisa bersekolah.

Menurut bu Aini yang juga mantan pengajar Madrasah Aliyah (MA), ia merasakan adanya ketimpangan jender dalam cara pandang masyarakat lokal terhadap profesi sebagai pengrajin gerabah. Masyarakat Lombok memandang bahwa pekerjaan sebagai pengarajin gerabah adalah pekerjaan perempuan. Jika ada suami yang membuat gerabah, maka masyarakat menjuluki dengan sebutan banci ${ }^{1}$. Cara pandang tersebut mengakibatkan terjadinya ketidakseimba ngan pembagian kerja antara suami dan istri dalam sebuah keluarga pengarajin. Tugas suami hanya mengangkut gerabah dari lokasi penjemuran ke tungku pembakaran. $\mathrm{Bu}$ Aini bertekad untuk mengubah cara pandang masyarakat lokal dengan pendekatan dan pendampingan kepada setiap keluarga. Usaha pendampingan dan pendekatan tersebut tak jarang mengundang pertentangan dan cibiran masyarakat setempat. Namun dengan ketekunan dan kesabaran yang memakan waktu delapan tahun, baru sekitar tahun 1998 terlihat hasil perubahan cara pandang masyarakat. Hal ini terlihat dari keikutsertaan para suami dalam proses produksi gerabah. Beberapa proses produksi kini mulai dilakukan oleh kaum lakilaki seperti mencampur bahan baku, membuat gerabah, membakar, bahkan menganyam aksesoris juga ditangani para suami. Perubahan cara pandang ini menjadikan beban kerja pengrajin perempuan menjadi lebih ringan.

Satu lagi hasil karya Bu Aini dalam hal edukasi masyarakat, yaitu masalah kesehatan lingkungan tempat tinggal. Tidak hanya mengurusi produksi gerabah, Bu Aini juga mengedukasi para pengrajinnya untuk

\footnotetext{
${ }^{2}$ Menurut Kamus Besar Bahasa Indonesia (KBBI) ban -ci $1 a$ tidak berjenis laki-laki dan juga tidak berjenis perempuan; $2 n$ laki-laki yg bertingkah laku dan berpakaian sbg perempuan; wadam; waria.
}

memiliki lingkungan tempat tinggal yang bersih dan sehat. Dahulu para pengrajin melakukan kegiatan mandi, cuci, dan kakus di sungai. Bu Aini kemudian mengajari para pengrajin untuk menyisihkan sebagian penghasilan mereka untuk mendapatkan rumah yang sehat. Sekarang para pengarajin di bawah asuhan bu Aini sudah memiliki kamar mandi dan kakus keluarga sendiri. Bu Aini juga memberikan pinjaman dana untuk pembangunan fasilitas kamar mandi dan kakus bagi pengrajinnya. Sama halnya dengan kebijakan pembayaran uang sekolah di TK, pengrajin juga boleh melunasi pinjaman tersebut dengan gerabah yang mereka produksi.

\section{F. Potensi Pengembangan Kerajian Gerabah Banyumulek}

$\mathrm{S}$ aat ini kondisi usaha gerabah Banyumulek tidak segemilang di awal tahun 1990-an. Kondisi perekonomian dunia yang mengalami krisis menjadikan permintaan ekspor gerabah ke luar negeri menurun drastis. Ditambah lagi kondisi keamanan dalam negeri yang satu dekade lalu dipenuhi oleh teror bom di beberada kota di Tanah Air, menjadikan sektor pariwisata terpuruk karena menurunnya jumlah kunjungan wisatawan. Misalnya saja pasca kejadian bom Bali pada bulan Oktober 2002 yang seketika mematikan usaha pariwisata di Bali dan Lombok, telah menurunkan hampir 50 persen penjualan hasil industri pariwisata. Padahal sebelum ledakan bom tersebut industri kerajinan gerabah Banyumulek dan daerah sentra lainnya di pulau Lombok mampu menyuplai 75 persen produknya ke pulau Bali dan 25 persen di ekspor ke luar negeri.

Walaupun diakui oleh beberapa pengarajin, kondisi saat ini belum benarbenar kembali seperti tahun-tahun sebelumnya, namun usaha untuk mem bangkitkan perekonomian masyarakat melalui gerabah mulai kembali dirintis. Bekal program pembimbingan dan bantuan dari pemerintah New Zealand tetap digunakan baik yang berupa modal fisik maupun modal skill dari para pengarajin dan pengusaha gerabah. Selain itu keseriusan pemerintah untuk memajukan kembali industri gerabah terlihat melalui program-program yang dicanangkan. Diantaranya menjadikan sektor pariwisata sebagai sektor unggulan 
daerah melalui program Visit Lombok Sumbawa 2012. Program ini menargetkan kunjungan wisatawan baik domestik maupun mancanegara mencapai 1 juta orang di tahun 2012. Salah satu pendorong meningkatnya kunjungan wisatawan ke Lombok adalah dengan dibukanya Bandara International Lombok pada tahun 2011.

$$
\text { Sentra kerajinan gerabah }
$$

Banyumulek saat ini dirancang sebagai destinasi wisata atraktif yang menampilkan bentuk wisata dengan memberikan pengalaman langsung membuat gerabah di lokasi pengrajin. Bentuk wisata baru ini mendapat respon positif dari berbagai kalangan terutama bagi para pelaku usaha sentra. Wisatawan yang berkunjung merupakan pasar yang potensial tidak hanya bagi pengrajin dan pemilik usaha, namun secara nyata juga dapat menghidupkan perekonomian setempat. Selain itu pemerintah daerah juga aktif memperkenalkan produksi gerabah Lombok melalui pameran-pameran baik di dalam maupun di luar negeri. Salah satu usaha penguatan produksi juga dilakukan dengan cara mendaftarkan hak paten produk gerabah lombok, termasuk gerabah Banyumulek.

\section{G. Penutup}

$\mathrm{P}$ erempuan dan gerabah di desa Banyumulek merupakan satu kesatuan yang tidak terpisahkan. Kerajinan gerabah bagi kaum perempuan bukan hanya sekedar keahlian yang diperoleh melalui garis keturunan, namun juga sebagai identitas sosial dan kultural masyarakat Banyumulek yang dinamis dan berkesinambungan. Kedinamisan dan kesinambungan kerajinan gerabah Banyumulek terlihat jelas dari transformasi fungsional gerabah yang berawal dari pemenuhan kebutuhan alat rumah tangga, berubah menjadi komoditas pasar hingga di ekspor ke manca negara.

Perubahan seni kerajinan gerabah tersebut secara langsung dirasakan berpengaruh terhadap aspek ekonomi, sosial dan budaya lokal. Perubahan yang terjadi juga dipengaruhi oleh perkembangan ilmu pengetahuan dan pengetahuan seni itu sendiri. Seperti dikemukakan Bakker (1983), perubahan itu berasal dari pengalaman baru, pengetahuan baru, teknologi baru dan akibatnya dalam penyesuaian cara hidup dan kebiasaan pada situasi baru. Namun di sisi lain, seni gerabah juga mengandung nilai kontinuitas. Kontinuitas berarti keberlangsungan kebiasaan-kebiasaan la ma yang dipertahankan atau dipelihara oleh tradisi sosial yang ditanamkan pada generasi penerus melalui sosialisasi, renovasi dan inovasi (Bakker, 1983).

Pandangan masyarakat lokal bahwa membuat gerabah adalah pekerjaan perempuan secara tidak langsung juga menjadi tantangan dalam pengembangan usaha gerabah. Cara pandang masyarakat lokal yang bias jender terkait beban kerja, menimalisir campur tangan kaum laki-laki dalam proses pembuatan gerabah. Kaum suami yang ikut membuat gerabah dipandang sebagai laki-laki yang kurang maskulin oleh masyarakat karena mengerjakan pekerjaan perempuan. Oleh karena itu dibutuhkan pendekatan yang memakan waktu lama untuk merubah cara pandang masyarakat lokal bahwa kerajinan gerabah bukan hanya domain perempuan, laki-laki pun dapat berkontribusi di dalamnya. Hal ini menjadi penting, menginggat jenis pekerjaan pada setiap proses pembuatannya membutuhkan tenaga yang cukup besar. Dengan mendapat bantuan dari tenaga kerja laki-laki dapat meringankan beban perempuan pengrajin dalam berproduksi.

Penguatan terhadap kapasitas perempuan pengrajin juga harus tetap diagendakan. Hal ini karena pelaku utama usaha kerajinan gerabah adalah perempuan. Strategi yang paling umum dilakukan adalah menempatkan perempuan secara langsung sebagai penerima manfaat utama (Holmes dan Jones, 2010). Bentuk bimbingan langsung kepada perempuan pengrajin berupa pelatihan teknis pembuatan, desain, dan pemasaran dinilai sukses meningkatkan kapasitas perempuan di desa Banyumulek. Selain itu hasilnya juga terlihat dari munculnya kader-kader perempuan yang memiliki jiwa wirausaha dan mampu untuk menjadi leader dalam pemberdayaan perempuan. Dengan perempuan yang berdaya dapat menjadi agen ekonomi yang dapat meningkatkan kesejahteraan keluarga. 


\section{Daftar Pustaka}

Atmadja, M.K. 1991. Perjalanan Seni Rupa Indonesia: Dari Zaman Prasejarah Hingga Masa Kini. Bandung. Panitia Pameran KIAS

Bakker, SJ. 1983. Filsafat Kebudayaan: Sebuah Pengantar. Jakarta. Kanisius.

Berata, M dan Muka, P. 2011. Gerabah Banyumulek Satu Tinjauan Budaya. Laporan Penelitian ISI Denpasar, Direktorat Jendral Pendidikan Tinggi Kementrian Pendidikan Nasional, 2010. http://repo.isi-dps.ac.id/756/1/banyumulekbab1.pdf. (diakses tanggal16 September 2014)

Holmes dan Jones, 2010. Rethinking Social Protection Using A Gender Lens. Working paper no. 320. London. ODI.

Kartodirdjo, Sartono dkk,. 1997. Sejarah Nasional Indonesia. Jilid I. Jakarta. Depdikbud.

McKinnon, Jean. 1996. Vessels of Life: Lombok Earthenware. Bali. Saritaksu.

Mudzhakar, Antho, dkk. 2001. Wanita Dalam Masyarakat Indonesia. Yogyakarta: Sunan Kalijaga Press.

Soedarso. 2006. Trilogi Seni: Penciptaan, Estetika, dan Kegunaan Seni . Yogyakarta. BP ISI

Soegondho, Santoso. 1995. Tradisi Gerabah di Indonesia: Dari Masa Prasejarah Hingga Masa Kini . Jakarta. Himpunan Keramik Indonesia

Soetrisno, Loekman. 1997. Kemiskinan, Perempuan, dan Pemberdayaan. Yogyakarta. Kanisius.

Soekanto, Soerjono. 1983. Teori Sosiologi Tentang Perubahan Sosial. Jakarta. Rajawali.

Sukardi, Lalu. 1997. Analisis Ekonomi Peran Ibu Rumah Tangga Pada Industri Kerajinan Gerabah di Pulau Lombok. Bogor. Institute Pertanian Bogor.

Vincentelli, Moira. 2006. Women Potters: Transforming Tradition. Rutgers University Press. New Jersey. USA.

Internet

www.jurnalperempuan.org/memande-kegiatan-ekonomi-perempuan-lombok.html

www.yskk.org/program/ekonomi-kerakyatan/pengembangan-koperasi-pengrajin-gerabah/ 